\title{
PHYSICAL PROPERTIES OF A RHODIC HAPLUSTOX UNDER TWO SUGARCANE HARVESTING SYSTEMS ${ }^{(1)}$
}

\author{
Walquíria Machado(2), Tiago Santos Telles ${ }^{(3)}$, João Tavares Filho(4), \\ Maria de Fátima Guimarães ${ }^{(4)}$, Grace Bungenstab Alves ${ }^{(5)}$ \& José \\ Luiz Bernardo Borges ${ }^{(3)}$
}

\begin{abstract}
SUMMARY
This study had the purpose of evaluating the effects of two management types of sugarcane: harvesting of burnt cane $(\mathrm{BCH})$ and mechanized harvesting of unburnt green cane $(\mathrm{MCH})$, on some soil physical properties of a dystrophic Rhodic Haplustox. The data were then compared with results for the same soil type under native forest. A completely randomized design was used, with three treatments and 20 replications. The following characteristics were determined: organic matter, aggregate stability, soil bulk density, and porosity at depths of $0-0.20 \mathrm{~m}$ and soil penetration resistance. After 15 years of cultivation, there were some alterations in the soil under cane burnt before harvesting, evidenced by a drop in the weighted average diameter of stable aggregates in water and increased soil bulk density. Significant changes were also detected in total porosity and pore distribution under both harvesting systems. Critical values for penetration resistance were observed in the area under mechanized sugar cane harvesting, with a value of $4.5 \mathrm{MPa}$ in the 40-55 $\mathrm{cm}$ layer. This value is considered high and could indicate compaction and restriction of root growth. Soil properties under the green cane (unburned) management system were closest to those of the soil under native forest.
\end{abstract}

Index terms: Saccharum officinarum, soil bulk density, porosity, soil penetration resistance, soil aggregate stability.

\footnotetext{
(1) Received for publication in February 2010 and approved in October 2010.

(2) Doutoranda do Programa de Pós-Graduação em Agronomia da Universidade Estadual de Londrina - UEL. Caixa Postal 6001, CEP 86051-990 Londrina (PR). Bolsista da CAPES. E-mail: w.mach@hotmail.com

(3) Mestre em Agronomia, UEL. E-mails: tiagotelles@yahoo.com.br; borges-jl@hotmail.com

(4) Professor do Departamento de Agronomia, UEL. E-mails: tavares@uel.br; mfatima@uel.br

(5) Mestre em Geografia, Universidade Estadual de Maringá - UEM. Av. Colombo 5790, CEP 87020-900 Maringá (PR). E-mail: bungenstabgrace@hotmail.com
} 


\title{
RESUMO: PROPRIEDADES FÍSICAS DE LATOSSOLO VERMELHO SOB DOIS SISTEMAS DE COLHEITA DE CANA-DE-AÇÚCAR
}

\begin{abstract}
Este trabalho foi conduzido em Latossolo-Vermelho distrófico, sob cultivo de cana-deaçúcar, com o objetivo de avaliar o efeito de dois sistemas de manejo, com (CCQ-corte manual de cana queimada com carregamento mecânico) e sem queima (CSQ - colheita mecânica de cana picada, crua), sobre propriedades físicas do solo. Os dados foram comparados com os resultados do mesmo solo sob mata nativa. O delineamento utilizado foi o inteiramente casualizado, com três tratamentos e 20 repetições. Foram determinadas a matéria orgânica, estabilidade de agregados, densidade e porosidade do solo, na profundidade de 0-0,20 m, e a resistência do solo à penetração. Após 15 anos de cultivo, constatou-se alteração do solo no sistema CCQ, evidenciada pela diminuição do diâmetro médio ponderado dos agregados estáveis em água e pelo aumento da densidade do solo. Foram também detectadas alterações significativas na porosidade total e distribuição de poros, devido às práticas de manejo nos dois sistemas de colheita. Valores críticos de resistência à penetração foram observados na área de cana mecanizada (CSQ), a 0,40-0,55 m de profundidade, sendo o valor (4,5 MPa) classificado como alto, podendo indicar compactação e restrição ao crescimento radicular. $O$ manejo mecanizado foi o sistema que apresentou características do solo mais próximas às da área de mata nativa.
\end{abstract}

Termos de indexação: Saccharum officinarum, densidade do solo, porosidade, resistência do solo à penetração, estabilidade dos agregados.

\section{INTRODUCTION}

Agricultural activities can affect the physical, chemical and biological properties of soil and environment (Lal, 2000; Souza et al., 2005) and inadequate management can lead to degradation and a drop in productivity (Bronick \& Lal, 2005).

In the State of São Paulo, areas covered by native forest were gradually replaced by coffee plantations and later by sugarcane in monoculture over lengthy periods (Oliveira et al., 1995). This substitution, along with continuous, prolonged, intensive cultivation and the applied management practices, is changing the natural conditions of the soil (Amézketa, 1999; Abiven et al., 2009).

On sugarcane plantations, the crop is usually burnt before harvesting, causing environmental problems such as emission of $\mathrm{C}$ monoxide $(\mathrm{CO})$ and other atmospheric pollutants, ash deposits in urban areas, physical exposure of the soil and loss of chemical fertility (Allen et al., 2004; Marques et al., 2009). To mitigate these problems, a mechanized system of green cane harvesting was developed that does not require burning and deposits the cane trash to cover over the soil, protecting it from erosion loss and improving soil conservation (Souza et al., 2005; Luca et al., 2008). In addition, the system of mechanized or green cane harvesting has proved promising, both in technical and economic terms (Rodrigues \& Saab, 2007).

The mechanized green harvesting of sugarcane can also increase the soil organic matter content and lead to more honmogenous micro and macropore distribution, improving aeration and water infiltration and retention, with an altogether positive effect on the soil physical and chemical quality (Canellas et al., 2003; Ng Cheong et al., 2009). Furthermore, the soil structure is improved and bulk density reduced, which means that more of the soil can be exploited by the roots (Passarin et al., 2007).

The reduced soil tillage on green cane plantations increases productivity (Canellas et al., 2003). Besides, in this system of mechanized harvesting without burning the leaves, sheaths, tips and variable quantities of stem sections are cut, shredded and cast over the soil surface, forming a cover of plant waste called "cane trash" (Souza et al., 2005). However, it is known that the traffic of machinery and equipment is one of the main factors involved in changing the soil physical properties (Sant'Anna et al., 2009). Therefore, burning the plantation causes great harm to soil and air quality (Allen et al., 2004). When cane is harvested green however, despite the increment in the layer of soil organic matter and improved physical and chemical soil quality (Canellas et al., 2003), the use of machinery under unsuitable humidity conditions can result in a series of changes in the soil physical properties (Severiano et al., 2008), including compaction (Ng Cheong et al., 2009).

The impact of different management systems on the soil physical quality has been quantified using different physical indicators related to the shape and structural stability of the soil, such as: bulk density (Llanillo et al. 2006), relative density (Carter, 1990; 
Hakansson \& Lipiec, 2000), porosity (Beutler et al., 2001; Oliveira et al., 2001), resistance to root penetration (Hammad \& Dawelbeit, 2001; Tavares Filho \& Ribon, 2008), aggregate stability (Amézketa, 1999), preconsolidation pressure (Dias Junior \& Pierce, 1996; Arvidsson \& Keller, 2004; Imhoff et al., 2004), Least Limiting Water Range (Severiano et al., 2008), and the S parameter (Dexter, 2004; Streck et al., 2008).

The aim of this study was to assess the influence of the two harvesting systems (burnt cane - $\mathrm{BCH}$, and green cane - $\mathrm{MCH}$ ) on some of the physical properties of a dystrophic Rhodic Haplustox soil and to compare the data with results for the same soil under native forest.

\section{MATERIAL AND METHODS}

The study commenced in September 2008, in the municipality of Paraguaçu Paulista $\left(22^{\circ} 29^{\prime} \mathrm{S}\right.$, $50^{\circ} 37^{\prime}$ W) in the state of São Paulo, Brazil, on a medium texture dystrophic Rhodic Haplustox (USA classification) or Latossolo Vermelho distrófico (Brazilian classification, Embrapa, 2006). The climate is classified in the Köppen system as subtropical temperate (Cwa), with hot, rainy summers with average temperatures above $22^{\circ} \mathrm{C}$, and winters with average temperatures below $18{ }^{\circ} \mathrm{C}$, with clearly-defined seasons and average annual rainfall of $1,359 \mathrm{~mm}$. The primary vegetation in the region is Savanna (Cerrado). The landscape is undulating, with average declivity from 3 to $8 \%$.

Sugarcane had been grown at the study location for 15 years. After each cycle of 5 to 7 harvests, the plantation was amended with appropriate treatments, using equipment for hoeing or scarifying, fertilizer application and cultivation that simultaneously scarify, apply fertilizer, till and prepare the land. This practice, followed by chemical treatment, is usually sufficient to keep the stumps clean.

A fully randomized experimental design was used, with three treatments and 20 replications for all parameters evaluated. The treatments consisted of the harvesting systems: (a) burning, manual cutting and mechanized loading of sugarcane $(\mathrm{BCH}),(\mathrm{b})$ mechanized harvesting of chopped unburned green cane $(\mathrm{MCH})$, and (c) native forest (NF), consisting of remaining primary vegetation, representing tropical savanna (Cerrado). The adjacent native forest area was used as reference for the initial state of the soil prior to cultivation.

Composite soil samples were collected after harvest from the 0-0.2 m layer, each consisting of four subsamples. A part of the samples were analyzed chemically (Table 1) and for organic matter content (Table 2) (Embrapa, 1997). The remaining sample quantities were used to determine (a) soil texture by the pipette method with organic matter oxidation (Tavares Filho \& Magalhães, 2008); (b) soil bulk density by the volumetric ring method (volume $50 \mathrm{~cm}^{3}$, diameter $15 \mathrm{~cm}$ ), collected from the litter layer between 0 and $10 \mathrm{~m}$; (c) total porosity, in terms of saturated soil mass and dry soil mass (oven at $10{ }^{\circ} \mathrm{C}$ for $24 \mathrm{~h}$ ); d) soil microporosity, determined by the tension table method; and e) macroporosity, determined by the difference between total porosity and microporosity (Embrapa, 1997).

Soil penetration resistance was also determined by the method described by Stolf (1991), at 20 points down to a depth of $0.70 \mathrm{~m}$, and the impact data in $\mathrm{dm}^{-1}$ were converted into dynamic strength $(\mathrm{MPa})$ using the formula: $\mathrm{RP}\left(\mathrm{kgf} \mathrm{cm}^{-2}\right)=5.6+6.89 \mathrm{~N}\left(\mathrm{dm}^{-1}\right.$ impact data). To convert the penetration resistance ( $\mathrm{RP}$ in $\mathrm{kgf} \mathrm{cm}^{-2}$ ) into dynamic strength $(\mathrm{MPa})$, the result obtained was multiplied by a constant (0.098). The saturation level was also determined in relation to the water volume ( $\mathrm{Va}$ ) and the total volume of voids in the soil $(\mathrm{Vv})$, expressed in percentage (Embrapa, 1997).

Aggregate stability in the $0-0.20 \mathrm{~m}$ layer was evaluated using the method proposed by Yoder, modified by Castro Filho et al. (1998). The mean weighted diameter (MWD), mean geometric diameter (MGD) and aggregate stability index (ASI) were determined.

The results were subjected to analysis of variance and the treatment means compared by the Tukey test at $5 \%$.

Table 1. Texture and chemical properties of a dystrophic Rhodic Haplustox in the 0-0.20 $\mathrm{m}$ layer under burnt cane harvesting $(\mathrm{BCH})$, mechanized cane harvesting $(\mathrm{MCH})$ and native forest $(\mathrm{NF})$

\begin{tabular}{|c|c|c|c|c|c|c|c|c|c|c|c|c|}
\hline Treatment & Clay & Silt & Sand & $\mathbf{P}$ & $\mathrm{pH} \mathrm{CaCl}{ }_{2}$ & $\mathrm{H}+\mathrm{Al}$ & $\mathrm{Al}^{3+}$ & $\mathrm{Ca}^{2+}$ & $\mathrm{Mg}^{2+}$ & $\mathbf{K}^{+}$ & CEC & $\mathbf{V}$ \\
\hline & & $\mathrm{g} \mathrm{kg}^{-}$ & & $m g \mathrm{dm}^{-3}$ & & 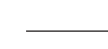 & 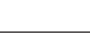 & $-\mathrm{cmol}_{\mathrm{C}}$ & $m^{-3}$ & & 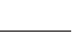 & $\%$ \\
\hline CCQ & 387 & 234 & 379 & 10.17 & 4.52 & 3.68 & 0.19 & 0.71 & 0.22 & 0.08 & 4.69 & 21.53 \\
\hline $\mathrm{CSQ}$ & 372 & 243 & 385 & 17.16 & 5.13 & 3.18 & 0.10 & 1.26 & 0.38 & 0.14 & 4.96 & 35.89 \\
\hline $\mathrm{MN}$ & 379 & 239 & 382 & 4.88 & 4.01 & 6.69 & 0.54 & 0.44 & 0.14 & 0.07 & 7.34 & 8.85 \\
\hline
\end{tabular}




\section{RESULTS AND DISCUSSION}

The results for organic matter (OM), macroporosity (Ma), microporosity (Mi), total porosity (TP) and soil bulk density (Ds) are given in table 2 .

There were significant differences in organic matter content for the management systems evaluated $(p<0.05)$. The organic matter content $\left(5.83 \mathrm{~g} \mathrm{~kg}^{-1}\right)$ of the $\mathrm{BCH}$ system was lower than $\mathrm{MCH}\left(19.23 \mathrm{~g} \mathrm{~kg}^{-1}\right)$, whereas the $\mathrm{MCH}$ system did not differ statistically from NF (19.97 $\left.\mathrm{g} \mathrm{kg}^{-1}\right)$.

The lowest organic matter content values obtained for the $\mathrm{BCH}$ system were due to burning before the harvest, which eliminates the cane trash on the soil surface. Ceddia et al. (1999) showed that the preharvest burn of cane trash is prejudicial to the conservation of organic matter in the soil, since it reduces the contribution of raw organic matter and promotes the mineralization of existing organic matter. The drops in macroporosity (Ma) and total porosity (TP) are the result of increasing microporosity (Mi) in soils managed by burning before harvesting, and are compatible with an increase in soil bulk density (Ds) and lower organic matter content compared with the soil under native forest.

Macroporosity and total porosity were higher in the soil under NF, differing statistically from $\mathrm{MCH}$ and $\mathrm{BCH}$. The microporosity values for $\mathrm{BCH}$ were significantly higher than those for the native forest area. MCH showed no difference in comparison to $\mathrm{BCH}$ and $\mathrm{NF}$.

In the BCH system, the soil surface is exposed to raindrop impact, mainly in the post-harvest period, which coincides with the period of highest average monthly rainfall (October to January), causing an increase in soil bulk density (Ds) and microporosity (Mi) and a drop in macroporosity (Ma) and total porosity (TP). In this context, Souza et al. (2005) confirmed that $\mathrm{Ma}$ is the most affected property by continuous sugarcane cropping.

In the $0-0.20 \mathrm{~m}$ layer, the increase in microporosity for both harvesting systems compared to native forest is due to the intense use of machinery, which compresses the pores in Haplustox soils. This was also reported by Silva \& Ribeiro (1997) in Yellow clayey Oxisol (Latossolo Amarelo argiloso) and by Sant'Anna et al. (2009) in Red-Yellow Oxisol (Latossolo VermelhoAmarelo).

Soil bulk density values for the $\mathrm{BCH}$ and $\mathrm{MCH}$ were the same, and significantly higher than soil bulk density under native forest. The increase in soil bulk density at a depth of $0.20 \mathrm{~m}$ is due to heavy machinery traffic during sugarcane planting and harvesting, mainly for the MCH system. These findings are in line with those of Hammad \& Dawelbeit (2001) and Silva et al. (2009), as the main cause of compaction in agricultural soils.

Soil penetration resistance (RP) was most uniform under native forest (NF) (Figure 1). A marked increase in penetration resistance was observed under $\mathrm{BCH}$, at a depth of $0.35 \mathrm{~m}$, and under $\mathrm{MCH}$, at a depth of $0.55 \mathrm{~m}$.

In the $\mathrm{MCH}$ system, the $\mathrm{RP}$ values were highest in the layer $0.40-0.55 \mathrm{~m}$, with values above $4.0 \mathrm{MPa}$,

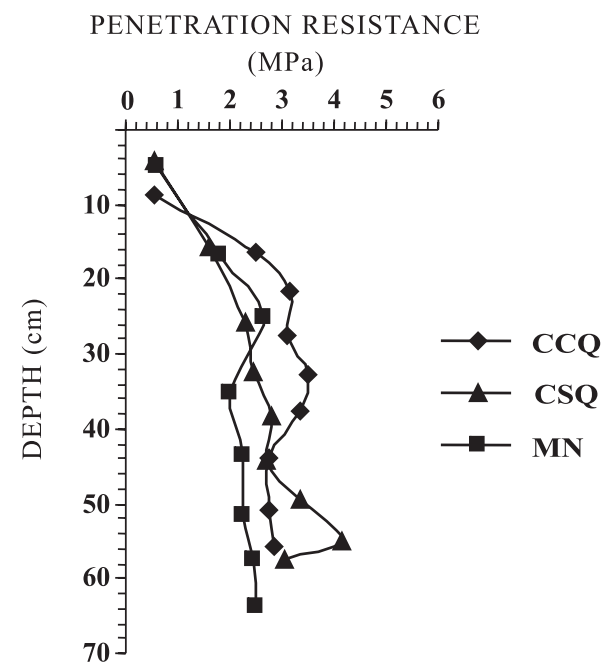

Figure 1. Resistance to vertical penetration in dystrophic Rhodic Haplustox to a depth of $0.70 \mathrm{~m}$ under burnt cane harvesting (BCH), mechanized cane harvesting (MCH), and native forest (NF).

Table 2. Results for organic matter (OM), macroporosity (Ma), microporosity (Mi), total porosity (TP) and soil bulk density (Ds) obtained in dystrophic Rhodic Haplustox, in the 0-0.20 m layer, under burnt cane harvesting $(\mathrm{BCH})$, mechanized cane harvesting $(\mathrm{MCH})$ and native forest $(\mathrm{NF})$

\begin{tabular}{|c|c|c|c|c|c|c|}
\hline \multirow{2}{*}{ Treatment } & \multirow{2}{*}{ OM } & \multicolumn{3}{|c|}{ Soil porosity } & \multirow{2}{*}{ Ds } & \multirow{2}{*}{ Soil saturation } \\
\hline & & Ma & Mi & TP & & \\
\hline & $\mathrm{g} \mathrm{kg}^{-1}$ & 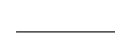 & $-m^{3} m^{-3}$ & - & $\mathrm{kg} \mathrm{m}^{-3}$ & $\%$ \\
\hline $\mathrm{BCH}$ & $5.83 \mathrm{~b}$ & $0.123 \mathrm{c}$ & $0.223 \mathrm{a}$ & $0.39 \mathrm{~b}$ & $1.57 \mathrm{a}$ & $56.06 \mathrm{~b}$ \\
\hline $\mathrm{MCH}$ & $19.23 \mathrm{a}$ & $0.172 \mathrm{~b}$ & $0.215 \mathrm{ab}$ & $0.35 \mathrm{c}$ & $1.55 \mathrm{a}$ & $64.60 \mathrm{a}$ \\
\hline $\mathrm{NH}$ & $19.97 \mathrm{a}$ & $0.231 \mathrm{a}$ & $0.206 \mathrm{~b}$ & $0.44 \mathrm{a}$ & $1.23 \mathrm{~b}$ & $47.36 \mathrm{c}$ \\
\hline
\end{tabular}

Values followed by the same letter were statistically not different in the Tukey test at $5 \%$. 
classified as high and very high, exceeding the critical level (Tavares Filho et al., 2001; Llanillo et al., 2006). However, even though the values were highest in this layer, no significant resistance to sugarcane root growth was observed in these systems, which would cause a restrictive effect to yield increases. In a study by Tavares Filho \& Ribon (2008), conservationist systems that involve less soil disturbance and an accumulation of organic matter showed the efficiency of root growth and microorganisms in structuring the soil, even at elevated penetration resistance values.

The highest penetration resistance value, found in the MCH system, is also related to heavy machinery traffic during cane harvesting. In areas of Oxisol (Latossolo), Tormena et al. (2004) attributed the naturally increased soil density to the management systems, highlighting the importance of using reference systems. Thus, a quantitative diagnosis (degree of soil compaction based on penetration resistance) (Ribon \& Tavares Filho, 2004) is desirable to verify the management quality.

Table 3 gives the results for aggregate particle size (class) distribution. Only in the classes $<0.25 \mathrm{~mm}$ and from 0.50 to $1.00 \mathrm{~mm}$ the differences between $\mathrm{BCH}$ and $\mathrm{MCH}$ were significant. $\mathrm{MCH}$ showed no differences in comparison to native forest for only two classes (0.50-1.00 mm and 1.00-2.00 mm), and BCH for only one class $(0.50-1.00 \mathrm{~mm})$. For the majority of classes under MCH and native forest, the aggregate particles were larger and more stable.

An analysis of aggregate stability in water showed that the use of machinery on the soil caused a drop in aggregates $>2 \mathrm{~mm}$ in the $\mathrm{BCH}$ and $\mathrm{MCH}$ systems, in contrast to the NF area, which contained a higher quantity of this aggregate class since it had not been affected by human activity.

Finally, the results for weighted average density, average geometric density and average stability index are given in figure 2. The area of native forest (NF) exhibited statistically higher values for MWD (3.78 mm), MGD (1.05 mm) and ASI (77.74\%). MWD showed significant differences between the two management systems, with a higher value for $\mathrm{MCH}$ $(1.55 \mathrm{~mm})$ than for $\mathrm{BCH}(0.84 \mathrm{~mm})$. However, in terms of MGD, there was little difference between the values for $\mathrm{BCH}(0.79 \mathrm{~mm})$ and $\mathrm{MCH}(0.87 \mathrm{~mm})$ and the ASI under green cane harvesting $(\mathrm{MCH})(65.45 \%)$ was higher than under burned cane harvesting $(\mathrm{BCH})$ (51.90\%).

The values for MWD and ASI were significantly lower in the $\mathrm{BCH}$ system (Figure 2), indicating lower soil quality than in MCH and NF, as stated by Souza et al. (2005). The lower MWD for BCH is related to cane trash burning and the consequent drop in organic matter content, as well as alterations in soil structure caused by the harvesting operations. In a Yellow Podzolic soil, Ceddia et al. (1999) verified a higher MWD in green cane as opposed to burnt cane, due to the higher organic matter content.

Of all areas studied, the MWD of the soil aggregates under NF was clearly the highest. According to Beutler

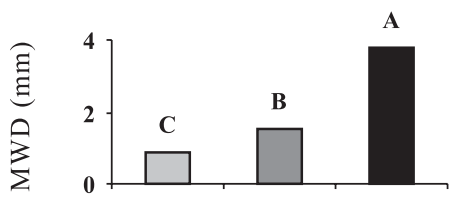

(a)

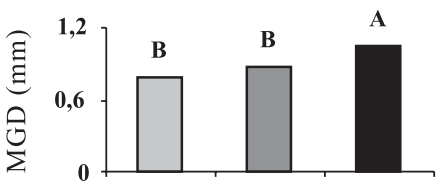

(b)

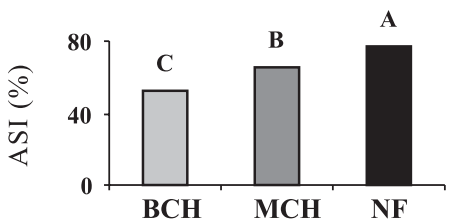

(c)

Figure 2. Mean Weighted Diameter - MWD (a), Mean Geometric Diameter - MGD (b) and Aggregate Stability Index - ASI (c) in the 0-0.20 m layer of a Rhodic Haplusdox, under burnt cane harvesting (BCH) and mechanized cane harvesting (MCH), and native forest (NF). Averages with different letters indicate significant differences in the Tukey test at $5 \%$.

Table 3. Aggregate particle size distribution in the $\mathbf{0 - 0 . 2 0} \mathrm{m}$ layer of a Rhodic Haplustox under burnt cane harvesting $(\mathrm{BCH})$ mechanized cane harvesting $(\mathrm{MCH})$, and native forest $(\mathrm{NF})$

\begin{tabular}{|c|c|c|c|c|c|c|}
\hline \multirow{2}{*}{ Treatment } & \multicolumn{6}{|c|}{ Aggregate particle size class (g) } \\
\hline & $<0.25$ & $0.25-0.50$ & $0.50-1.00$ & $1.00-2.00$ & $2.00-8.00$ & $8.00-19.00$ \\
\hline $\mathrm{BCH}$ & $22.65 \mathrm{a}$ & $16.22 \mathrm{a}$ & $2.87 \mathrm{~b}$ & $1.20 \mathrm{~b}$ & $2.91 \mathrm{~b}$ & $0.82 \mathrm{~b}$ \\
\hline $\mathrm{MCH}$ & $17.44 \mathrm{~b}$ & $18.04 \mathrm{a}$ & $4.19 \mathrm{a}$ & $1.67 \mathrm{ab}$ & $3.43 \mathrm{~b}$ & $1.15 \mathrm{~b}$ \\
\hline $\mathrm{NH}$ & $10.37 \mathrm{c}$ & $10.13 \mathrm{~b}$ & $3.43 \mathrm{ab}$ & $2.14 \mathrm{a}$ & $12.63 \mathrm{a}$ & $7.89 \mathrm{a}$ \\
\hline
\end{tabular}

Values followed by different letters indicate significant differences in the Tukey test at $5 \%$. 
et al. (2001), the aggregates of Cerrado soils are larger and more stable, due to the physical effects of the roots and the constant layer of organic residues on the soil surface, associated with the action of macro and microorganisms, resulting in the formation of composts with cementing and stabilizing action.

An analysis of the aggregate stability for MGD (Figure 2) generally showed values of less than $1 \mathrm{~mm}$ for $\mathrm{MCH}$ and $\mathrm{BCH}$. Significant differences were observed when the MGD values for the $\mathrm{MCH}$ and $\mathrm{BCH}$ systems were compared with those for native forest. Although no significant difference was observed for particles $\geq 1.00 \mathrm{~mm}$, compared with the soil under $\mathrm{BCH}$, the $\mathrm{MCH}$ system had a greater quantity of larger particles and a higher MWD. Thus, MCH proved more suitable for conservation of the soil structural quality, for being more similar to the soil under native forest.

Higher aggregate stability under MCH was due to the higher organic matter content which affected soil particle aggregation, in line with the observations of Camilotti et al. (2005) and Severiano et al. (2008). Furthermore, ASI under MCH was closer to that of the native forest soil, showing that appropriately managed systems enable the maintenance of the soil physical aggregates close to the ideal (Amézketa, 1999; Beutler et al. 2001; Abiven et al., 2009).

In general, the indicators for soil physical properties under $\mathrm{BCH}$ were less favorable and generally more distant from the conditions of native forest. Advantages in terms of organic matter content and aggregate stability were observed under $\mathrm{MCH}$, despite limitations with regard to soil bulk density and penetration resistance.

\section{CONCLUSIONS}

1. Mechanized harvesting without crop burning is advantageous in terms of organic matter content and aggregate stability, but limited with regard to soil bulk density and penetration resistance.

2. The indicators of the soil physical properties under burnt cane harvesting were less favorable, and differed more from the soil conditions under native forest.

\section{ACKNOWLEDGEMENTS}

We are indebted to CAPES (Brazilian Federal Agency for Support and Evaluation of Graduate Education) and CNPq (National Council of Scientific and Technological Development) for funding the study and wish to express our thanks to the Usina Nova América/COSAN for the permission to carry out the study in their plantation areas.

\section{LITERATURE CITED}

ABIVEN, S.; MENASSERI, S. \& CHENU, C. The effects of organic inputs over time on soil aggregate stability: A literature analysis. Soil Biol. Biochem., 41:1-12, 2009.

ALLEN, A.G.; CARDOSO, A.A. \& ROCHA, G.O. Influence of sugar cane burning on aerosol soluble ion composition in Southeastern Brazil. Atmospheric Environ., 38:50255038, 2004.

AMÉZKETA, E. Soil aggregate stability: A review. J. Sustain. Agric., 14:83-151, 1999.

ARVIDSSON, J. \& KELLER, T. Soil precompression stress. I. A survey of Swedish arable soils. Soil Till. Res., 77:85-95, 2004.

BEUTLER, A.N.; SILVA, M.L.N.; CURI, N.; FERREIRA, M.M.; CRUZ, J.C. \& PEREIRA FILHO, I.A. Resistência à penetração e permeabilidade de Latossolo Vermelho distrófico típico sob sistemas de manejo na região dos Cerrados. R. Bras. Ci. Solo, 25:167-177, 2001.

BRONICK, C.J. \& LAL, R. Soil structure and management: A review. Geoderma, 124:3-22, 2005.

CAMILOTTI, F.; ANDRIOLI, I.; DIAS, F.I.F.; CASAGRANDE, A.A.; SILVA, A.R.; MUTTON, M.A. \& CENTURION, J.F. Efeito prolongado de sistemas de preparo do solo com e sem cultivo de soqueira de cana crua em algumas propriedades físicas do solo. Eng. Agric., 25:189-198, 2005.

CANELlAS, L.P.; VELloso, A.C.X.; MARCIANO, C.R.; RAMALHO, J.F.G.P.; RUMJANEK, V.M.; REZENDE, C.E. \& SANTOS, G.A. Propriedades químicas de um Cambissolo cultivado com cana-de-açúcar, com preservação do palhiço e adição de vinhaça por longo tempo. R. Bras. Ci. Solo, 27:935-944, 2003.

CARTER, M.R. Relative measures of soil bulk density to characterize compaction in tillage studies of fine sandy loams. Canadian J. Soil Sci., 70:425-433, 1990.

CASTRO FILHO, C.; MUZILLI, O. \& PODANOSCHI, A.L. Estabilidade dos agregados e sua relação com o teor de carbono orgânico num Latossolo Roxo distrófico, em função de sistemas de plantio, rotações de culturas e métodos de preparo das amostras. R. Bras. Ci. Solo, 22:527538, 1998.

CEDDIA, M.B.; ANGOS, L.H.C.; LIMA, E.; RAVELLI NETO, A. \& SILVA, L.A. Sistemas de colheita da cana-de-açúcar e alterações nas propriedades físicas de um solo Podzólico Amarelo no Estado do Espírito Santo. Pesq. Agropec. Bras., 34:1467-1473, 1999.

DEXTER A.R. Soil physical quality: Part I. Theory, effects of soil texture, density, and organic matter, and effects on root growth. Geoderma, 120:201-214, 2004.

DIAS JUNIOR, M.S. \& PIERCE, F.J. O processo de compactação do solo e sua modelagem. R. Bras. Ci. Solo, 20:175-182, 1996.

EMPRESA BRASILEIRA DE PESQUISA AGROPECUÁRIA EMBRAPA. Centro Nacional de Pesquisa de Solos. Manual de métodos de análise de solos. 2.ed. Rio de Janeiro, 1997. 212p. 
EMPRESA BRASILEIRA DE PESQUISA AGROPECUÁRIA EMBRAPA. Centro Nacional de Pesquisa de Solos. Sistema brasileiro de classificação de solos. 2.ed. Rio de Janeiro, 2006. 306p.

HAKANSSON, I. \& LIPIEC, J. A review of the usefulness of relative bulk density values in studies of soil structure and compaction. Soil Till. Res., 53:71-85, 2000.

HAMMAD, E.A. \& DAWELBEIT, M.I. Effect of tillage and field condition on soil physical properties, cane and sugar yields in Vertisols of Kenana Sugar Estate, Sudan. Soil Till. Res., 62:101-109, 2001.

IMHOFF, S.; SILVA, A.P. \& FALLOW, D. Susceptibility to compaction, load support capacity, and soil compressibility of Hapludox. Soil Sci. Soc. Am. J., 68:17-24, 2004.

LAL, R. Soil management in the developing countries. Soil Sci., 165:57-72, 2000.

LLANILLO, R.F.; RICHART, A.; TAVARES FILHO, J.; GUIMARÃES, M.F. \& FERREIRA, R.R.M. Evolução de propriedades físicas do solo em função dos sistemas de manejo em culturas anuais. Semina: Ci. Agr., 27:205$220,2006$.

LUCA, E.F.; FELLER, C.; CERRI, C.C.; BARTHES, B.; CHAPLOT, V.; CAMPOS, D.C. \& MANECHINI, C. Avaliação de atributos físicos e estoques de carbono e nitrogênio em solos com queima e sem queima de canavial. R. Bras. Ci. Solo, 32:789-800, 2008.

MARQUES, T.A.; SASSO, C.G.; SATO, A.M. \& SOUZA, G.M. Queima do canavial: Aspectos sobre a biomassa vegetal, fertilidade do solo e emissão de $\mathrm{CO}_{2}$ para atmosfera. Biosci. J., 25:83-89, 2009.

NG CHEONG, L.R.; NG KEE KWONG, K.F.; AH KOON, P.D. \& DU PREEZ, C.C. Changes in an Inceptisol of Mauritius after rock removal for sugar cane production. Soil Till. Res., 104:88-96, 2009

OLIVEIRA, J.C.M.; VAZ, C.M.P. \& REICHARDT, K. Efeito do cultivo contínuo da cana-de-açúcar em propriedades físicas de um Latossolo Vermelho-Escuro. Sci. Agric., 52:50-55, 1995.

OLIVEIRA, J.O.A.P.; VIDIGAL FILHO, P.S.; TORMENA, C.A.; PEQUENO, M.G.; SCAPIM, C.A.; MUNIZ A.S. \& SAGRILO, E. Influência de sistemas de preparo do solo na produtividade da mandioca (Manihot esculenta, Crantz). R. Bras. Ci. Solo, 25:443-450, 2001.

PASSARIN, A.L.; RODRIGUEIRO, E.L.; ROBAINA, C.R.P. \& MEDINA, C.C. Caracterização de agregados em um Latossolo Vermelho distroférrico típico submetido a diferentes doses de vinhaça. R. Bras. Ci. Solo, 31:1255$1260,2007$.

RIBON, A.A. \& TAVARES FILHO, J. Models for the estimation of the physical quality of a Yellow Red Latosol (Oxisol) under pasture. Braz. Arch. Biol. Technol., 47:25-31, 2004.
RODRIGUES, E.B. \& SAAB, O.J.G.A. Avaliação técnicoeconômica da colheita manual e mecanizada da cana-deaçúcar (Saccharum spp.) na região de Bandeirantes - Pr. Semina: Ci. Agr., 28:581-588, 2007.

SANT'ANNA, S.A.C.; FERNANDES, M.F.; IVO W.M.P.M. \& COSTA, J.L.S. Evaluation of soil quality indicators in sugarcane management in sandy loam soil. Pedosphere, 19:312-322, 2009.

SEVERIANO, E.C.; OLIVEIRA, G.C.; DIAS JÚNIOR, M.S.; OLIVEIRA, L.F.C. \& CASTRO, M.B. Pressão de préconsolidação e intervalo hídrico ótimo como indicadores de alterações estruturais de um Latossolo e de um Cambissolo sob cana-de-açúcar. R. Bras. Ci. Solo, 32:14191427, 2008.

SILVA, A.J.N. \& RIBEIRO, M.R. Caracterização de Latossolo Amarelo sob cultivo contínuo de cana-de-açúcar no Estado de Alagoas: Atributos morfológicos e físicos. R. Bras. Ci. Solo, 21:677-684, 1997.

SILVA, R.B.; LANÇAS, K.P.; MIRANDA, E.E.V.; SILVA, F.A.M. \& BAIO, F.H.R. Estimation and evaluation of dynamic properties as indicators of changes on soil structure in sugarcane fields of São Paulo State - Brazil. Soil Till. Res., 103:265-270, 2009

SOUZA Z.M.; PRADO R.M.; PAIXÃO A.C.S. \& CESARIN, L.G. Sistemas de colheita e manejo da palhada de cana-deaçúcar. Pesq. Agropec. Bras., 40:271-278, 2005.

STOLF, R. Teoria e teste experimental de fórmulas de transformação dos dados de penetrômetro de impacto em resistência do solo. R. Bras. Ci. Solo, 15:229-235, 1991.

STRECK, C.A.; REINERT, D.J.; REICHERT, J.M. \& HORN, R. Relações do parâmetro S para algumas propriedades físicas de solos do sul do Brasil. R. Bras. Ci. Solo, 32:2603$2612,2008$.

TAVARES FILHO, J. \& MAGALHÃES, F.S. Dispersão de amostras de Latossolo Vermelho eutroférrico influenciadas por pré-tratamento para oxidação da matéria orgânica e pelo tipo de agitação mecânica. R. Bras. Ci. Solo, 32:1429-1435, 2008.

TAVARES FILHO, J. \& RIBON, A.A. Resistência do solo à penetração em resposta ao número de amostras e tipo de amostragem. R. Bras. Ci. Solo, 32:487-494, 2008.

TAVARES FILHO, J.M.C.; BARBOSA, G.; GUIMARÃES, M.F. \& FONSECA, I.C.B. Resistência à penetração e desenvolvimento do sistema radicular do milho (Zea mays) sob diferentes sistemas de manejo em Latossolo Roxo. R. Bras. Ci. Solo, 25:725-720, 2001.

TORMENA, C.A.; FRIEDRICH, R.; PINTRO, J.C.; COSTA, A.C.S. \& FIDALSKI, J. Propriedades físicas e taxa de estratificação de carbono orgânico num Latossolo Vermelho após dez anos sob dois sistemas de manejo. R. Bras. Ci. Solo, 28:1023-1031, 2004. 